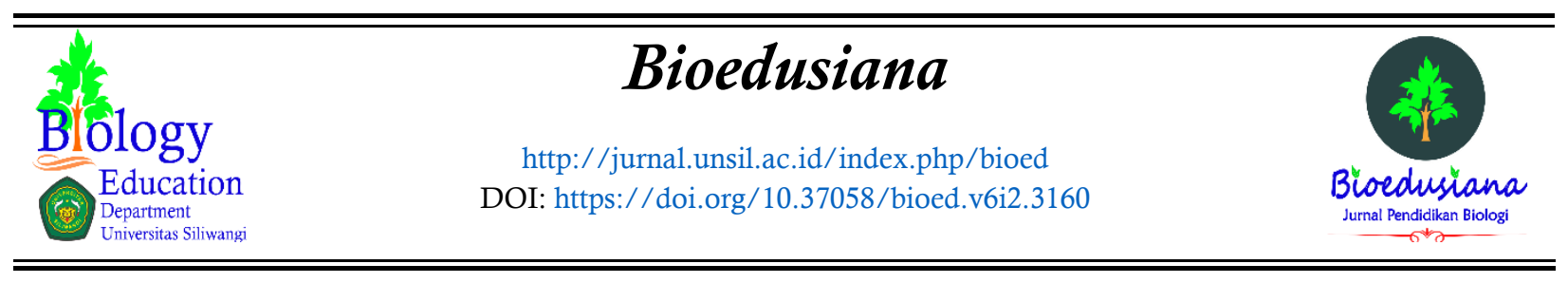

\title{
Kelayakan Media Video Animasi Powtoon pada Submateri Peran Tumbuhan di Bidang Ekonomi Kelas X SMA dalam Pembuatan Biskuit Pisang Ambon Lumut
}

\section{Eligibility of the Powtoon Animation Video Media in the Submaterial of Plant Roles in the Economy Sector of the Class X SMA in the Making of Ambon Lumut Banana Biscuit}

\author{
Sasmita Dewi ${ }^{1}$, Entin Daningsih ${ }^{2 *}$, Titin $^{3}$ \\ 1,2,3 Program Studi Pendidikan Biologi FKIP Universitas Tanjungpura, J1. Prof. Dr. H. Hadari Nawawi, \\ Pontianak, Kalimantan Barat 78124
}

\begin{abstract}
Abstrak
Keterbatasan waktu dalam pelaksanaan kegiatan pembelajaran untuk pencapaian kompetensi yang diharapkan menjadi salah satu kendala yang harus disiasati oleh para pendidik. Materi biasanya disampaikan dengan ceramah tanpa memberikan stimulan agar peserta didik dapat mengolah makanan dari tumbuhan di sekitarnya. Submateri peran tumbuhan di bidang ekonomi memerlukan contoh faktual yang dapat meningkatkan kreativitas peserta didik untuk mengoptimalkan tumbuhan lokal. Penelitian ini bertujuan mengetahui kelayakan media video animasi Powtoon pada submateri peran tumbuhan di bidang ekonomi kelas X SMA dalam pembuatan biskuit pisang ambon lumut. Metode

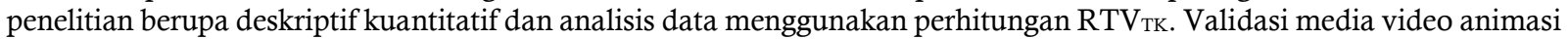
Powtoon dilakukan oleh tiga orang ahli materi dengan tiga aspek dan tujuh kriteria penilaian serta tiga orang ahli media dengan enam aspek dan 13 kriteria penilaian. Hasil validasi media video animasi Powtoon memperoleh nilai RTVTK sebesar 3,57 oleh ahli materi dan 3,62 oleh ahli media. Media video animasi Powtoon berdasarkan nilai rata-rata total validasi dinyatakan valid karena memenuhi kriteria validitas yaitu $3 \leq \mathrm{RTV}_{\mathrm{TK}} \leq 4$ dan menunjukkan media video animasi Powtoon layak digunakan sebagai media pembelajaran pada submateri peran tumbuhan di bidang ekonomi kelas X SMA.
\end{abstract}

Kata kunci: Kelayakan; Media Video Animasi Powtoon; Biskuit Pisang Ambon Lumut

\begin{abstract}
Limited time in implementing learning activities for the achievement of competencies that are expected to be one of the obstacles that educators must deal with. The material is usually delivered with lectures without providing stimulants so that students can process food from the surrounding plants. The submaterial of the role of plants in the economy requires factual examples that can increase the creativity of students to optimize local plants. This study aimed to determine the eligibility of Powtoon animation video media in the submaterial of the role of plants in the economic of class X SMA in making ambon lumut banana biscuit. The research method was quantitative descriptive and data analysis using $R T V_{T K}$ calculation. Powtoon animation video media validation was carried out by three material experts with three aspects and seven assessment criteria and three media experts with six aspects and 13 assessment criteria. The results of the validation of the Powtoon animation video media obtained an $R T V_{T K}$ value of 3.57 by material experts and 3.62 by media experts. Powtoon animation video media based on the average value of total validation was declared valid because it meets the validity criteria, namely $3 \leq R T V_{T K} \leq 4$ and shows Powtoon animation video media is feasible to be used as a learning medium in the submaterial of the role of plants in the economic of class X SMA.
\end{abstract}

Keywords: Eligibility; Animation Media of Powtoon Video; Ambon Lumut Banana Biscuit

Article History

Received: June 12 ${ }^{\text {th }}, 2021$; Accepted: November $6^{\text {th }}, 2021$; Published: December $31^{\text {st }}, 2021$

Corresponding Author*

Entin Daningsih, Program Studi Pendidikan Biologi FKIP Universitas Tanjungpura, E-mail: entin.daningsih@fkip.untan.ac.id

(C) 2021 Bioedusiana. This is an open access article under the CC BY-SA 4.0 license

(https://creativecommons.org/licenses/by-sa/4.0/) 


\section{PENDAHULUAN}

Pada pembelajaran biologi terdapat materi-materi yang tidak hanya dipelajari secara teori tetapi juga dipraktikkan. Biologi juga banyak dikaitkan dengan kehidupan sehari-hari. Peserta didik semestinya mendapatkan pembelajaran yang konkret agar mereka dapat memahami materi yang dipelajari. Guru sebagai seorang pendidik harus mampu memilih metode atau media pembelajaran yang sesuai dengan materi. Nurrita (2018) menyatakan bahwa media pembelajaran merupakan alat yang dapat membantu proses belajar mengajar sehingga makna pesan yang disampaikan menjadi lebih jelas dan tujuan pembelajaran dapat tercapai dengan baik.

Media pembelajaran yang digunakan untuk membantu proses pembelajaran diarahkan dapat menyalurkan pesan, merangsang pikiran, perasaan, perhatian, dan kemauan peserta didik sehingga dapat mendorong terjadinya proses belajar yang disengaja, bertujuan, dan terkendali seperti yang dinyatakan oleh Suryani, Setiawan, \& Putria (2018). Media yang digunakan dalam pembelajaran beranekaragam mulai dari media cetak sampai media audiovisual (Arsyad, 2016; Munadi, 2013; Sadiman, Rahardjo, Haryono, \& Harjito, 2014). Untuk memilih media yang dapat memberikan pembelajaran yang berkualitas, tidak hanya mempertimbangkan kerucut pengalaman Edgar Dale dan gaya belajar peserta didik tetapi juga cara penggunaannya baik oleh guru maupun peserta didik (Sari, 2019). Pada kerucut pengalaman Edgar Dale, seseorang dapat menyerap melalui kegiatan belajar dari visual, audiovisual, sampai pengalaman langsung dari 30\% sampai 90\%. Dibandingkan dengan media cetak yang dapat dilihat 30\% penyerapan, gabungan media audio dan visual memberikan 50\% penyerapan. Dengan tingginya persentase penyerapan ini dibandingkan dengan media cetak maka media audiovisual akan memberikan dampak yang lebih baik.

Media audiovisual adalah media pembelajaran yang melibatkan indra pendengaran dan penglihatan sekaligus dalam satu proses (Arsyad, 2016; Munadi, 2013; Sadiman et al., 2014). Salah satu bentuk media audiovisual adalah media video animasi Powtoon. Kelebihan media video animasi Powtoon adalah adanya fitur animasi yang beragam serta efek transisi yang menarik. Selain itu, pengaturan timeline pada aplikasi dapat dianggap lebih mudah dibandingkan aplikasi-aplikasi lain yang sejenis (Ernalida et al., 2018). Media video animasi Powtoon juga menyediakan proses interaktif dan memberikan umpan balik, bisa digunakan dimana dan kapan saja secara mandiri, dan aplikasi yang digunakan dalam penyusunan multimedia interaktif Powtoon sangat menarik sehingga produk yang dihasilkan juga memiliki kualitas gambar, animasi, video, suara dan musik yang lebih baik (Pangestu \& Wafa, 2018). Selanjutnya Juliana, Erviyenni, \& Rini (2017) mengembangkan media pembelajaran berbasis Powtoon pada pokok bahasan struktur atom di kelas X SMA mendapatkan ratarata nilai validasi ahli media dan ahli materi sebanyak $88,04 \%$ serta dikategorikan baik $(82,14 \%)$ oleh guru dan peserta didik. 
Media video animasi Powtoon yang didesain menyajikan tentang materi peran tumbuhan di bidang ekonomi. Submateri peran tumbuhan di bidang ekonomi tertulis dalam KD 3.8 tentang menerapkan prinsip klasifikasi untuk menggolongkan tumbuhan ke dalam divisio berdasarkan pengamatan dan metagenesis tumbuhan serta mengaitkan peranannya dalam kelangsungan kehidupan di bumi. Materi ini termasuk salah satu subpokok bahasan pada pembelajaran biologi kelas $\mathrm{X}$ pada semester dua.

Berdasarkan wawancara dengan guru Biologi kelas X SMA Negeri 4 Sungai Raya Kabupaten Kubu Raya bahwa proses pembelajaran yang dilakukan pada materi Plantae tidak hanya bersifat teori dengan menggunakan metode ceramah, diskusi, presentasi, tanya jawab, tetapi juga observasi langsung dengan melakukan inventarisasi tumbuhan yang ada di lingkungan sekitar pada submateri peran tumbuhan di bidang ekonomi. Secara teori peserta didik sudah memahami submateri tersebut dengan ketuntasan 100\% pada nilai KKM 75 dan nilai rata-rata peserta didik 89,51.

Berdasarkan pencapaian nilai KKM oleh peserta didik tersebut menunjukkan bahwa submateri peran tumbuhan di bidang ekonomi telah dipahami dengan baik, namun di sisi lain banyak produk tumbuhan yang ada di sekitar lingkungan belum terkelola dengan optimal. Kondisi tumbuhan yang belum digunakan secara optimal di lingkungan sekitar peserta didik dapat menjadi inspirasi kepada peserta didik dalam mengembangkan produk dengan menggunakan tumbuhan di sekitarnya sehingga mempunyai nilai ekonomi yang lebih tinggi. Pendekatan pembelajaran yang tepat dalam melaksanakan proses pembelajaran untuk ini adalah learning by doing (belajar dengan melakukan sesuatu). Learning by doing merupakan salah satu pendekatan yang dapat diterapkan dalam pembelajaran biologi termasuk pada submateri peran tumbuhan di bidang ekonomi. Pendekatan pembelajaran tersebut dilakukan dengan kegiatan sederhana yang dapat menggambarkan konsep yang sedang dipelajari secara faktual. Dengan begitu, peserta didik dapat mengalami sendiri tidak hanya mengetahui secara teoritis tetapi juga praktik namun kegiatan praktik biasanya memerlukan waktu yang lebih lama (Astuti, 2015). Oleh sebab itu, penelitian ini mengembangkan kegiatan pembuatan biskuit dari pisang ambon lumut dengan berbantuan media video animasi Powtoon untuk mengefektifkan waktu sehingga peserta didik dapat mendapatkan pengalaman dalam membuat produk makanan dengan mengoptimalkan penggunaan tumbuhan di sekitarnya.

Media video animasi Powtoon yang didesain memuat tentang peran tumbuhan di bidang ekonomi khususnya pisang ambon lumut atau Musa paradisiaca var. sapientum. Pisang termasuk komoditi tumbuhan yang melimpah di Kalimantan Barat dengan produksi pisang mencapai 72.848ton atau 24,92\% (Badan Pusat Statistik Kalimantan Barat, 2018). Pisang ambon lumut hanya di konsumsi sebagai buah meja sekalipun mempunyai kandungan nutrisi dan serat yang tinggi (Hasanah, 
Daningsih, \& Titin, 2017). Pisang ambon lumut dapat digunakan sebagai bahan tambahan yang bergizi dalam pembuatan biskuit yang belum diproduksi di Kalimantan Barat.

Berdasarkan uraian tersebut, maka tujuan penelitian ini adalah untuk membuat dan mengetahui kelayakan media video animasi Powtoon pada submateri peran tumbuhan di bidang ekonomi kelas X SMA dalam pembuatan biskuit pisang ambon lumut.

\section{METODE}

Penelitian ini menggunakan metode deskriptif kuantitatif. Prosedur pelaksanaan dalam penelitian ini meliputi beberapa tahap yaitu tahap persiapan, tahap pelaksanaan, dan tahap akhir. Pada tahap persiapan adalah melakukan studi pustaka dari beberapa sumber internet, buku, jurnal serta sumber lainnya terkait penelitian yang dilakukan; kemudian melakukan pra riset untuk mengumpulkan data dengan cara melakukan wawancara dan observasi ke sekolah; selanjutnya dilakukan pembuatan media video animasi Powtoon dan dievaluasi menggunakan lembar validasi instrumen untuk ahli materi dan ahli media. Pada tahap kedua, media dievaluasi kelayakannya dan melakukan revisi berdasarkan saran dan komentar yang diberikan oleh validator. Pada tahap akhir adalah analisis data hasil validasi media dengan mengacu pada Yamasari (2010).

Alat yang digunakan dalam penelitian ini adalah laptop, Powtoon, Audacity, dan InShot. Audacity pada penelitian ini digunakan untuk merekam dan memberikan efek suara, sedangkan InShot digunakan untuk mengedit video. Bahan yang digunakan dalam penelitian ini adalah materi-materi pembelajaran dan gambar-gambar yang mendukung dari beberapa sumber internet, buku, jurnal serta sumber lainnya terkait materi tentang tiga divisi tumbuhan secara umum dan submateri peran tumbuhan di bidang ekonomi, musik instrumen menggunakan lagu anak gembala, hasil dokumentasi proses pembuatan biskuit pisang ambon lumut, referensi tambahan terkait uji organoleptik pada makanan, dan lembar validasi media video animasi Powtoon.

Instrumen penelitian yang digunakan pada penelitian ini berupa lembar uji kelayakan instrumen validasi media video animasi Powtoon (Tabel 1 dan 2), lembar validasi media video animasi Powtoon ahli materi (Tabel 3) dan ahli media (Tabel 4).

Tabel 1. Lembar Instrumen Validasi Media Video Animasi Powtoon Ahli Materi

\begin{tabular}{|c|c|c|c|c|c|c|c|c|c|c|c|c|c|c|c|}
\hline \multirow{3}{*}{ No. } & \multirow{3}{*}{ Aspek Penilaian } & \multicolumn{14}{|c|}{ Kriteria Penilaian Ke- } \\
\hline & & \multicolumn{2}{|c|}{1} & \multicolumn{2}{|c|}{2} & \multicolumn{2}{|c|}{3} & \multicolumn{2}{|c|}{4} & \multicolumn{2}{|c|}{5} & \multicolumn{2}{|c|}{6} & \multicolumn{2}{|c|}{7} \\
\hline & & $\mathbf{Y}$ & $\mathbf{T}$ & $\mathbf{Y}$ & $\mathbf{T}$ & $\mathbf{Y}$ & $\mathbf{T}$ & $\mathbf{Y}$ & $\mathbf{T}$ & $\mathbf{Y}$ & $\mathbf{T}$ & $\mathbf{Y}$ & $\mathbf{T}$ & $\mathbf{Y}$ & $\mathbf{T}$ \\
\hline 1. & $\begin{array}{l}\text { Kesesuaian kriteria dengan } \\
\text { aspek yang dinilai }\end{array}$ & & & & & & & & & & & & & & \\
\hline
\end{tabular}




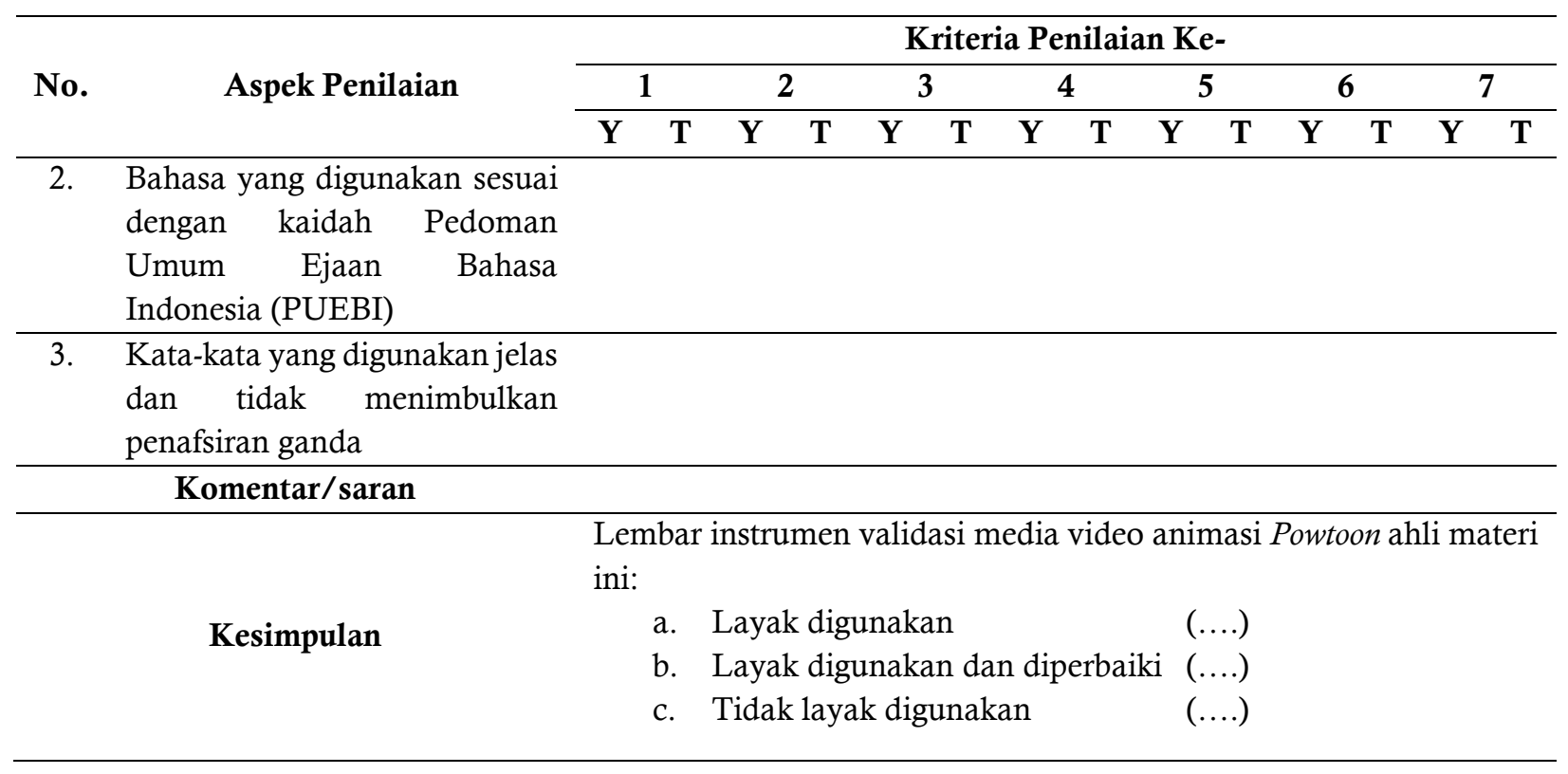

Tabe1 2. Lembar Instrumen Validasi Media Video Animasi Powtoon Ahli Media

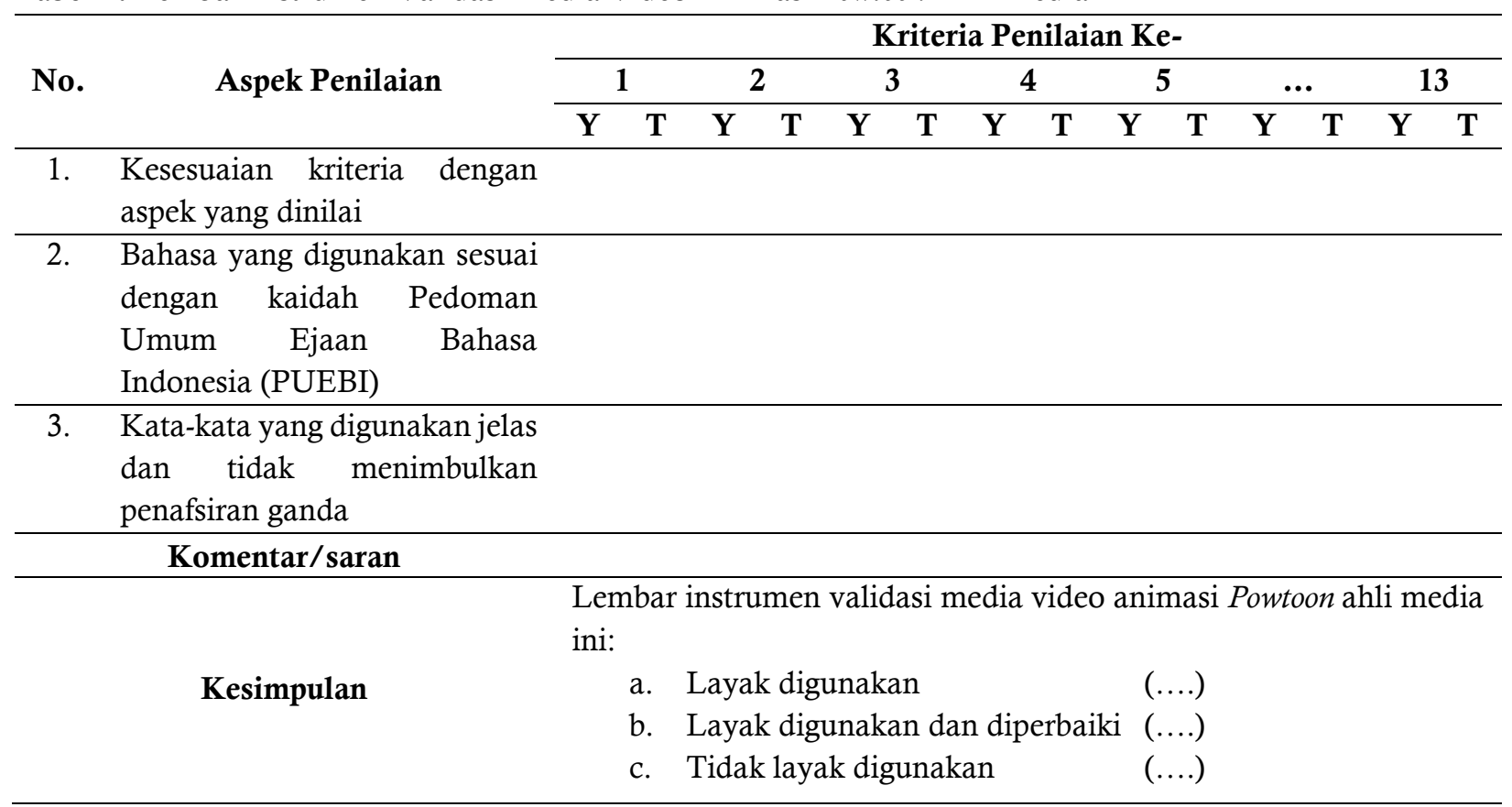

Pengisian lembar instrumen validasi media video animasi Powtoon pada Tabel 1 dan 2 tersebut dilakukan dengan memberikan tanda checklist $(\sqrt{ })$ pada kolom Y $(Y a)$ atau T (Tidak) terhadap suatu kriteria penilaian untuk mendapatkan kesimpulan layak digunakan (LD), layak digunakan dan diperbaiki (LDP), atau tidak layak digunakan (TLD). 
Tabel 3. Kisi-kisi Lembar Validasi Media Video Animasi Powtoon Ahli Materi

\begin{tabular}{|c|c|c|}
\hline No. & Aspek & Kriteria Penilaian \\
\hline \multirow[t]{2}{*}{1.} & Format & $\begin{array}{l}\text { 1. Ketersediaan petunjuk penggunaan media video animasi } \\
\text { Powtoon }\end{array}$ \\
\hline & & $\begin{array}{l}\text { 2. Kesesuaian warna, tampilan gambar, dan tulisan pada media } \\
\text { video animasi Powtoon dengan submateri pembelajaran yang } \\
\text { ditampilkan }\end{array}$ \\
\hline \multirow[t]{3}{*}{2.} & Isi & $\begin{array}{l}\text { 3. Kesesuaian submateri pada media video animasi Powtoon dengan } \\
\text { kompetensi dasar, indikator pencapaian kompetensi, dan tujuan } \\
\text { pembelajaran }\end{array}$ \\
\hline & & $\begin{array}{l}\text { 4. Kemudahan memahami submateri yang disampaikan pada } \\
\text { media video animasi Powtoon }\end{array}$ \\
\hline & & $\begin{array}{l}\text { 5. Kelengkapan informasi yang disampaikan pada media video } \\
\text { animasi Powtoon }\end{array}$ \\
\hline \multirow[t]{2}{*}{3.} & Bahasa & $\begin{array}{l}\text { 6. Bahasa yang digunakan sesuai dengan terminologi dan tingkat } \\
\text { pendidikan }\end{array}$ \\
\hline & & $\begin{array}{l}\text { 7. Penggunaan kalimat sesuai dengan Pedoman Umum Ejaan } \\
\text { Bahasa Indonesia (PUEBI) }\end{array}$ \\
\hline
\end{tabular}

Tabel 4. Kisi-kisi Lembar Validasi Media Video Animasi Powtoon Ahli Media

\begin{tabular}{|c|c|c|}
\hline No. & Aspek & Kriteria Penilaian \\
\hline \multirow[t]{4}{*}{1.} & \multirow[t]{4}{*}{ Kesederhanaan } & 1. Kemudahan dalam mengakses media video animasi Powtoon \\
\hline & & $\begin{array}{l}\text { 2. Kemudahan dalam mengoperasikan media video animasi } \\
\text { Powtoon }\end{array}$ \\
\hline & & $\begin{array}{l}\text { 3. Kesesuaian animasi yang disajikan dalam media video animasi } \\
\text { Powtoon dengan karakteristik peserta didik }\end{array}$ \\
\hline & & $\begin{array}{l}\text { 4. Kemudahan dalam memahami kalimat yang digunakan pada } \\
\text { media video animasi Powtoon }\end{array}$ \\
\hline \multirow[t]{4}{*}{2.} & \multirow[t]{4}{*}{ Keterpaduan } & 5. Kesesuaian urutan antar frame dengan narasi \\
\hline & & $\begin{array}{l}\text { 6. Ketepatan pemilihan backsound pada media video animasi } \\
\text { Powtoon }\end{array}$ \\
\hline & & 7. Sinkronisasi antara backsound dan suara narator \\
\hline & & $\begin{array}{l}\text { 8. Ketepatan dalam pemilihan background pada media video } \\
\text { animasi Powtoon }\end{array}$ \\
\hline 3. & Penekanan & 9. Penekanan intonasi suara narator pada frame tertentu \\
\hline & \multirow[t]{2}{*}{ Keseimbangan } & $\begin{array}{l}\text { 10. Kejelasan gambar dan tulisan yang digunakan dalam media } \\
\text { video animasi Powtoon }\end{array}$ \\
\hline & & $\begin{array}{l}\text { 11. Keseimbangan tata letak tulisan pada tiap frame yang digunakan } \\
\text { dalam media video animasi Powtoon }\end{array}$ \\
\hline 5. & Bentuk & 12. Fleksibilitas dalam penggunaan media video animasi Powtoon \\
\hline & Warna & $\begin{array}{l}\text { 13. Penggunaan warna yang sesuai pada tiap frame dalam media } \\
\text { video animasi Powtoon }\end{array}$ \\
\hline
\end{tabular}


Instrumen penelitian tersebut divalidasi oleh validator ahli materi dan ahli media yang bertujuan mengetahui kelayakan media video animasi Powtoon agar dapat digunakan dalam kegiatan pembelajaran di sekolah. Pemilihan validator dilakukan dengan menggunakan teknik purposive sampling. Validasi pada penelitian ini dilakukan dalam dua tahap yaitu validasi instrumen dan validasi media video animasi Powtoon (validasi ahli materi dan ahli media). Validasi instrumen media video animasi Powtoon dilakukan oleh masing-masing dua orang validator ahli materi dan ahli media. Sedangkan untuk validasi media video animasi Powtoon dilakukan oleh masing-masing tiga orang validator ahli materi dan ahli media. Validator ahli materi meliputi satu orang dosen Pendidikan Biologi FKIP Universitas Tanjungpura dan dua orang guru Biologi yang berasal dari SMA Negeri 1 Sungai Raya dan SMA Negeri 2 Sungai Raya. Sedangkan validator ahli media meliputi dua orang dosen Pendidikan Biologi FKIP Universitas Tanjungpura dan satu orang guru TIK yang berasal dari SMA Negeri 2 Sungai Raya. Lembar validasi media video animasi Powtoon ahli materi terdapat tiga aspek dan tujuh kriteria penilaian, sedangkan lembar validasi media video animasi Powtoon ahli media terdapat enam aspek dan 13 kriteria penilaian. Aspek materi dan media yang dikembangkan pada media video animasi Powtoon merupakan hasil modifikasi dari Yamasari (2010). Analisis data hasil validasi media video animasi Powtoon merujuk kepada Khabibah (Yamasari, 2010).

\section{HASIL DAN PEMBAHASAN}

Media video animasi Powtoon didesain menjadi tiga bagian yaitu pembukaan, isi, dan penutup dengan durasi selama 16 menit 26 detik. Media video animasi Powtoon merupakan aplikasi online berbasis audiovisual yang memiliki beragam fitur animasi seperti kartun, tulis tangan, dan efek transisi yang menarik serta tersedia juga tulisan, background, backsound, voice over, dan pengaturan timeline yang mudah dioperasikan. Beberapa tampilan media video animasi Powtoon pada submateri peran tumbuhan di bidang ekonomi kelas X SMA dengan pembuatan biskuit pisang ambon lumut (Musa paradisiaca var. sapientum) dan uji organoleptik yang terlihat pada Gambar 1, 2, 3, dan 4.

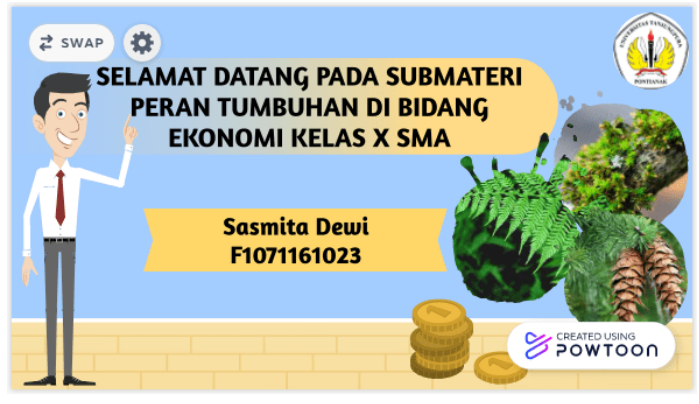

(a)

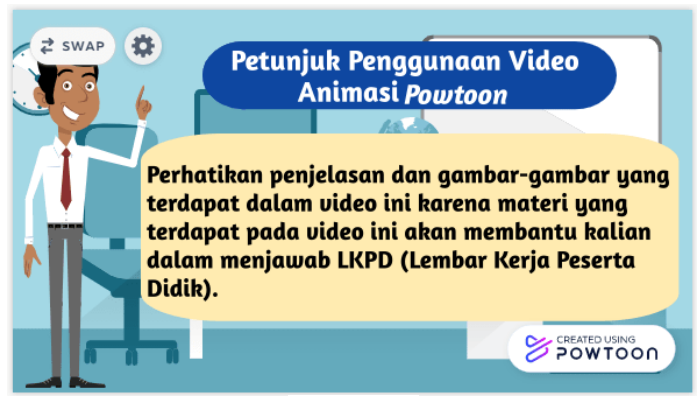

(b)

Gambar 1. Tampilan Bagian Pembukaan pada Media Video Animasi Powtoon yang meliputi (a) Cover atau Judul Media Video Animasi Powtoon; dan (b) Petunjuk Penggunaan Media Video Animasi Powtoon 


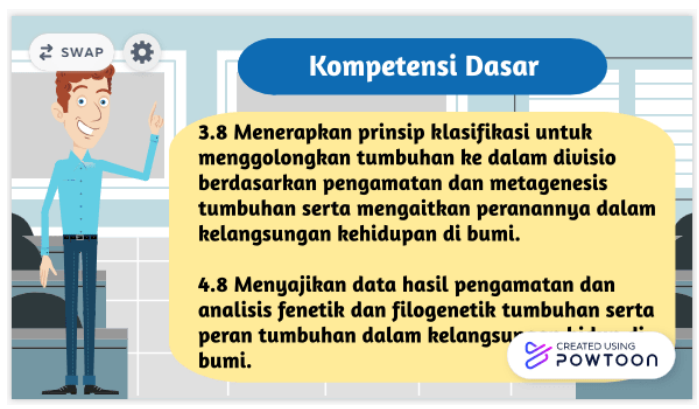

(a)

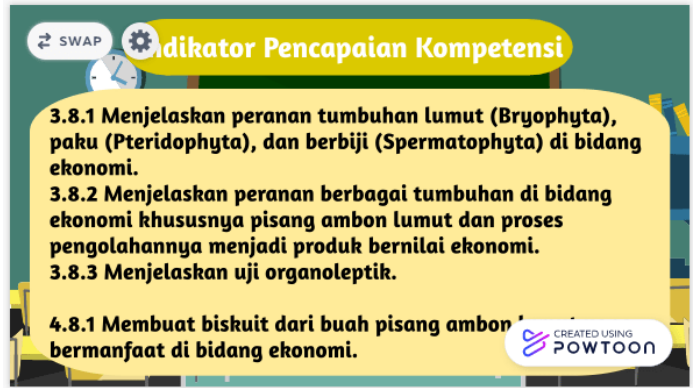

(b)

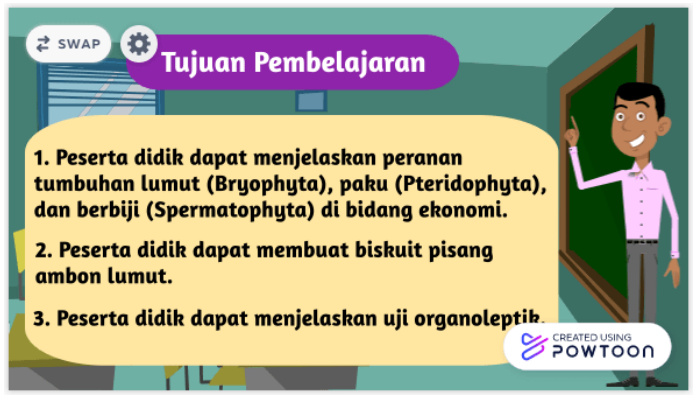

(c)

Gambar 2. Tampilan Bagian Pembukaan pada Media Video Animasi Powtoon yang meliputi (a) Kompetensi Dasar; (b) Indikator Pencapaian Kompetensi; dan (c) Tujuan Pembelajaran

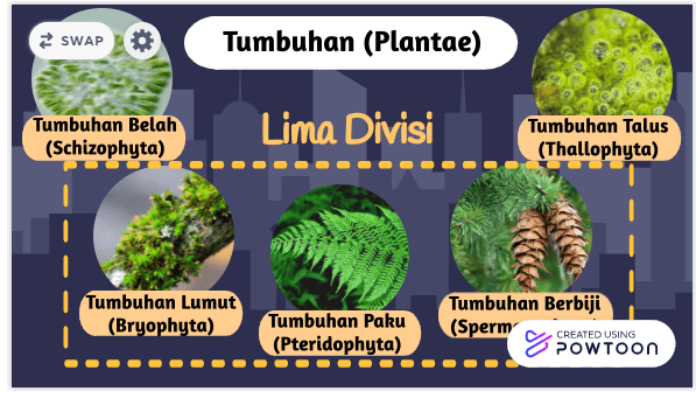

(a)

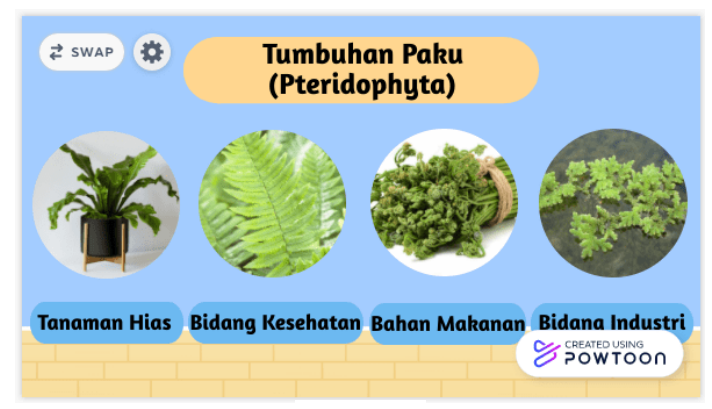

(c)

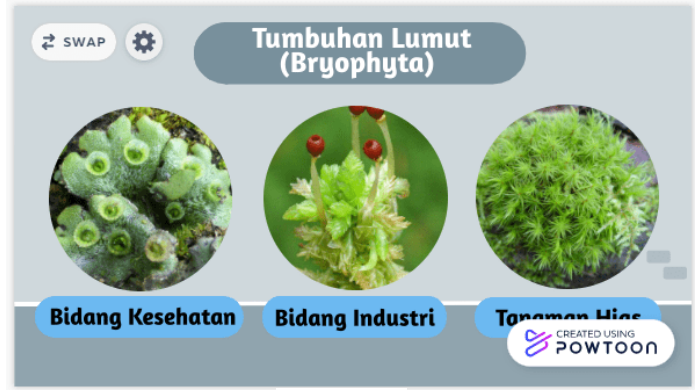

(b)

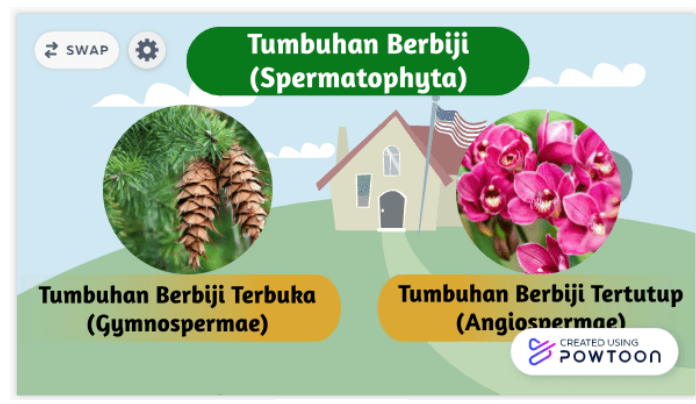

(d)

Gambar 3. Tampilan Bagian Isi pada Media Video Animasi Powtoon yang meliputi (a) Penjelasan Tiga Divisi Tumbuhan secara Umum; (b) Peranan Tumbuhan Lumut di Bidang Ekonomi; (c) Peranan Tumbuhan Paku di Bidang Ekonomi; dan (d) Pengelompokan Tumbuhan Berbiji 


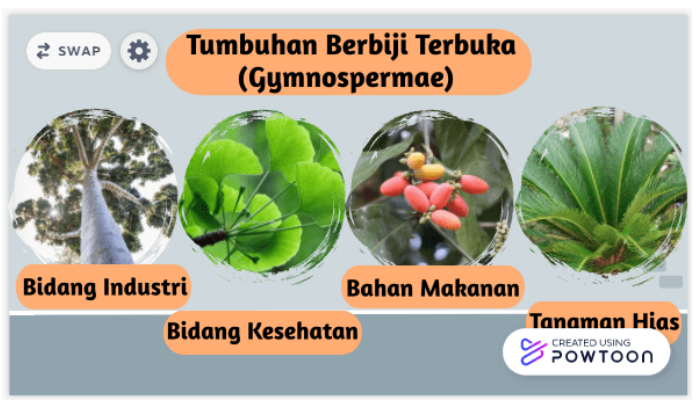

(a)

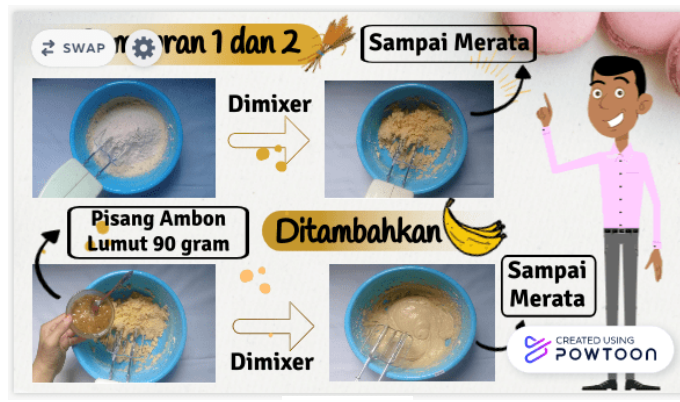

(c)

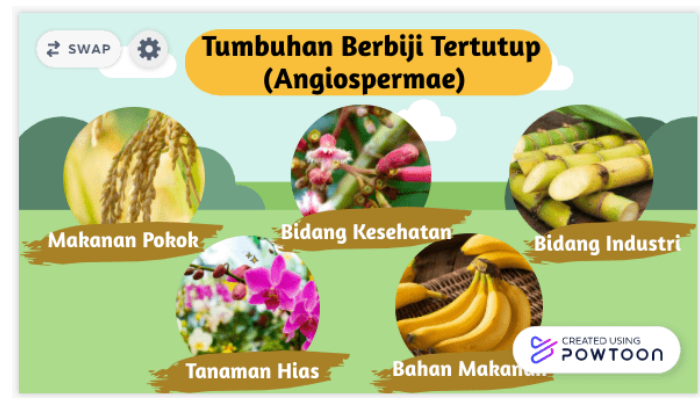

(b)

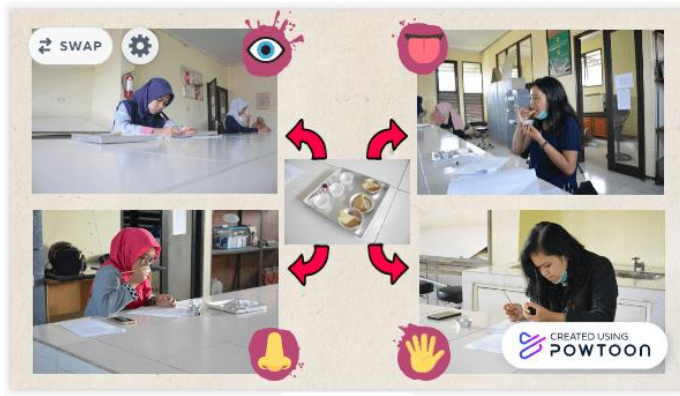

(d)

Gambar 4. Tampilan Bagian Isi pada Media Video Animasi Powtoon yang meliputi (a) Peranan Tumbuhan Berbiji Terbuka di Bidang Ekonomi; (b) Peranan Tumbuhan Berbiji Tertutup di Bidang Ekonomi; (c) Cara Pembuatan Biskuit Pisang Ambon Lumut; dan (d) Uji Organoleptik

Selanjutnya media video animasi Powtoon yang telah selesai didesain, divalidasi dengan tujuan untuk mengetahui kelayakannya dalam kegiatan pembelajaran di sekolah. Validasi media video animasi Powtoon dinilai kelayakannya oleh tiga orang validator ahli materi yang meliputi satu orang dosen Pendidikan Biologi FKIP Untan dan dua orang guru Biologi yang berasal dari SMA Negeri 1 Sungai Raya dan SMA Negeri 2 Sungai Raya. Aspek materi yang dikembangkan pada media video animasi Powtoon merupakan hasil modifikasi dari Yamasari (2010) meliputi aspek format, isi, dan bahasa yang dimuat menjadi tujuh kriteria penilaian. Hasil analisis data validasi media video animasi Powtoon oleh validator ahli materi tertulis pada Tabel 5.

Tabel 5. Hasil Analisis Data Validasi Media Video Animasi Powtoon oleh Validator Ahli Materi

\begin{tabular}{|c|c|c|c|c|c|c|c|}
\hline \multirow{2}{*}{ No. } & \multirow{2}{*}{ Aspek } & \multirow{2}{*}{ Kriteria Penilaian } & \multicolumn{3}{|c|}{ Validator ke- } & \multirow{2}{*}{$\mathbf{K i}$} & \multirow{2}{*}{$\mathbf{A} \mathbf{i}$} \\
\hline & & & 1 & 2 & 3 & & \\
\hline \multirow[t]{2}{*}{1.} & Format & $\begin{array}{l}\text { 1. Ketersediaan petunjuk penggunaan } \\
\text { media video animasi Powtoon }\end{array}$ & 4 & 4 & 4 & 4 & 3,66 \\
\hline & & $\begin{array}{l}\text { 2. Kesesuaian warna, tampilan gambar, } \\
\text { dan tulisan pada media video animasi } \\
\text { Powtoon dengan submateri pembelajaran } \\
\text { yang ditampilkan }\end{array}$ & 3 & 3 & 4 & 3,33 & \\
\hline 2. & Isi & $\begin{array}{l}\text { 3. Kesesuaian submateri pada media video } \\
\text { animasi Powtoon dengan kompetensi }\end{array}$ & 3 & 4 & 4 & 3,66 & 3,55 \\
\hline
\end{tabular}




\begin{tabular}{|c|c|c|c|c|c|c|c|}
\hline \multirow{2}{*}{ No. } & \multirow{2}{*}{ Aspek } & \multirow{2}{*}{ Kriteria Penilaian } & \multicolumn{3}{|c|}{ Validator ke- } & \multirow{2}{*}{$\mathbf{K i}$} & \multirow{2}{*}{$\mathbf{A i}$} \\
\hline & & & 1 & 2 & 3 & & \\
\hline & & $\begin{array}{l}\text { dasar, indikator pencapaian kompetensi, } \\
\text { dan tujuan pembelajaran }\end{array}$ & & & & & \\
\hline & & $\begin{array}{l}\text { 4. Kemudahan memahami submateri yang } \\
\text { disampaikan pada media video animasi } \\
\text { Powtoon }\end{array}$ & 4 & 3 & 3 & 3,33 & \\
\hline & & $\begin{array}{l}\text { 5. Kelengkapan informasi yang } \\
\text { disampaikan pada media video animasi } \\
\text { Powtoon }\end{array}$ & 4 & 3 & 4 & 3,66 & \\
\hline \multirow[t]{2}{*}{3.} & Bahasa & $\begin{array}{l}\text { 6. Bahasa yang digunakan sesuai dengan } \\
\text { terminologi dan tingkat pendidikan }\end{array}$ & 4 & 4 & 4 & 4 & 3,5 \\
\hline & & $\begin{array}{l}\text { 7.Penggunaan kalimat sesuai } \\
\text { Pedoman Umum Ejaan } \\
\text { Indonesia (PUEBI) }\end{array}$ & 3 & 3 & 3 & 3 & \\
\hline
\end{tabular}

Keterangan:

Ki $\quad$ : Rata-rata tiap kriteria

Ai $\quad$ : Rata-rata tiap aspek

$\mathrm{RTV}_{\mathrm{TK}} \quad$ : Rata-rata total validitas

Berdasarkan hasil analisis data validasi media oleh validator ahli materi (Tabel 5) menunjukkan bahwa media video animasi Powtoon yang didesain termasuk dalam kategori valid dengan hasil $\mathrm{RTV}_{\mathrm{TK}}$ sebesar 3,57. Sejalan dengan itu hasil perhitungan Ai juga dinyatakan valid karena memenuhi kriteria validitas berdasarkan Khabibah (dalam Yamasari, 2010) yaitu $3 \leq \mathrm{RTV}_{\mathrm{TK}}$ $\leq 4$.

Nilai RTV $_{\text {TK }}$ yang termasuk dalam kriteria valid yang menunjukkan bahwa media video animasi Powtoon yang didesain pada penelitian ini layak untuk digunakan sebagai media pembelajaran pada submateri peran tumbuhan di bidang ekonomi kelas X SMA dalam pembuatan biskuit pisang ambon lumut. Selanjutnya revisi dilakukan berdasarkan saran dan komentar dari validator.

Aspek format yang dinilai pada media video animasi Powtoon terdiri dari dua kriteria penilaian. Kriteria penilaian yang pertama pada aspek format yaitu ketersediaan petunjuk penggunaan media video animasi Powtoon (Gambar 1b) yang dilengkapi dengan cover (Gambar 1a). Pangestu (2017) menyatakan ketersediaan petunjuk penggunaan media yang telah disediakan membantu seseorang menggunakan media tersebut untuk mengetahui dan mengerti cara-cara penggunaannya beserta tujuan yang akan dicapai. Kriteria penilaian yang kedua pada aspek format yaitu kesesuaian warna, tampilan gambar, dan tulisan pada media video animasi Powtoon dengan submateri pembelajaran yang ditampilkan. Istiqomah, Daningsih, \& Yokhebed (2016) menyatakan penggunaan warna, gambar, dan tulisan yang sesuai dapat membantu penyampaian konsep-konsep pada materi agar tampak lebih konkret. Aspek format secara keseluruhan dinyatakan valid dengan Ai sebesar 3,66. 
Kedua kriteria penilaian dinyatakan valid dengan perolehan Ki sebesar 4 dan 3,33 sehingga memenuhi kriteria kelayakan untuk digunakan sebagai media pembelajaran oleh peserta didik.

Pada aspek format terdapat kriteria penilaian kesesuaian warna, tampilan gambar, dan tulisan pada media video animasi Powtoon dengan submateri pembelajaran yang ditampilkan mendapatkan saran perbaikan dari validator ahli materi untuk memperbesar ukuran tulisan sehingga terbaca oleh semua peserta didik. Pangestu (2017) menyetujui bahwa tulisan harus dapat terbaca agar peserta didik memahami materi yang dilihat.

Aspek isi yang dinilai pada media video animasi Powtoon terdiri dari tiga kriteria penilaian yaitu kesesuaian submateri pada media video animasi Powtoon dengan kompetensi dasar (Gambar 2a), indikator pencapaian kompetensi (Gambar 2b), dan tujuan pembelajaran (Gambar 2c), beserta kemudahan memahami submateri dan kelengkapan informasi yang disampaikan pada media video animasi Powtoon (Gambar 3a, 3b, 3c, 3d, 4a, 4b, 4c, dan 4d). Nurrita (2018) menyatakan media yang dipilih dan digunakan oleh pendidik harus sesuai dengan tujuan pembelajaran yang telah ditetapkan sehingga kegiatan belajar mengajar efektif dan materi yang disampaikan mudah dipahami. Aspek isi secara keseluruhan dinyatakan valid dengan Ai sebesar 3,55. Ketiga kriteria penilaian dinyatakan valid dengan perolehan masing-masing Ki sebesar 3,66, 3,33, dan 3,66. Penilaian validator ahli materi terhadap media video animasi Powtoon menunjukkan bahwa materi yang disajikan pada media sesuai dengan kompetensi dasar, indikator pencapaian kompetensi, dan tujuan pembelajaran. Sehingga aspek isi pada media video animasi Powtoon telah memenuhi seluruh kriteria.

Aspek bahasa yang dinilai pada media video animasi Powtoon terdiri dari dua kriteria penilaian. Pada aspek bahasa kriteria penilaian pertama yaitu bahasa yang digunakan sesuai dengan terminologi dan tingkat pendidikan dinyatakan valid dengan memperoleh Ki sebesar 4 yang menunjukkan bahwa bahasa yang digunakan sederhana, baik sehingga mudah dimengerti, dan tata tulis yang digunakan untuk mengungkapkan makna konsep memenuhi kriteria yang telah ditentukan. Dewi (2015) menyatakan bahwa narasi atau bahasa yang digunakan harus mudah dimengerti oleh peserta didik sehingga lebih mudah mengerti materi yang disajikan. Kriteria penilaian kedua pada aspek bahasa yaitu penggunaan kalimat sesuai dengan Pedoman Umum Ejaan Bahasa Indonesia (PUEBI) dinyatakan valid dengan memperoleh Ki sebesar 3. Prastowo (2013) menyatakan bahwa media memiliki standar bahasa yang meliputi penggunaan bahasa yang baik dan benar, peristilahan yang memenuhi Pedoman Umum Ejaan Bahasa Indonesia (PUEBI), bahasa yang digunakan memiliki kejelasan, dan kemudahan untuk memahami. Aspek bahasa secara keseluruhan dinyatakan valid dengan Ai sebesar 3,5 sehingga aspek bahasa pada media video animasi Powtoon telah memenuhi seluruh kriteria. 
Media video animasi Powtoon selain divalidasi oleh validator ahli materi, media ini juga divalidasi oleh validator ahli media. Validasi media video animasi Powtoon dinilai kelayakannya oleh tiga orang validator ahli media yang meliputi dua orang dosen Pendidikan Biologi FKIP Untan dan satu orang guru TIK SMA Negeri 2 Sungai Raya. Aspek media yang dikembangkan pada media video animasi Powtoon merupakan hasil modifikasi dari Yamasari (2010) meliputi aspek kesederhanaan, keterpaduan, penekanan, keseimbangan, bentuk, dan warna yang dikembangkan menjadi 13 kriteria penilaian. Hasil analisis data validasi media video animasi Powtoon oleh validator ahli media tertulis pada Tabel 6.

Tabel 6. Hasil Analisis Data Validasi Media Video Animasi Powtoon oleh Validator Ahli Media

\begin{tabular}{|c|c|c|c|c|c|c|c|}
\hline \multirow{2}{*}{ No. } & \multirow{2}{*}{ Aspek } & \multirow{2}{*}{ Kriteria Penilaian } & \multicolumn{3}{|c|}{ Validator ke- } & \multirow{2}{*}{$\mathbf{K i}$} & \multirow{2}{*}{$\mathbf{A i}$} \\
\hline & & & 1 & 2 & 3 & & \\
\hline \multirow[t]{4}{*}{1.} & \multirow[t]{4}{*}{ Kesederhanaan } & $\begin{array}{l}\text { 1. Kemudahan dalam mengakses } \\
\text { media video animasi Powtoon }\end{array}$ & 4 & 4 & 4 & 4 & \multirow[t]{4}{*}{3,83} \\
\hline & & 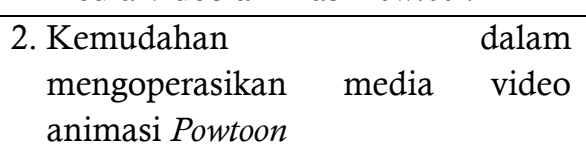 & 4 & 4 & 4 & 4 & \\
\hline & & $\begin{array}{l}\text { 3. Kesesuaian animasi yang disajikan } \\
\text { dalam media video animasi Powtoon } \\
\text { dengan karakteristik peserta didik }\end{array}$ & 4 & 3 & 3 & 3,33 & \\
\hline & & $\begin{array}{l}\text { 4. Kemudahan dalam memahami } \\
\text { kalimat yang digunakan pada media } \\
\text { video animasi Powtoon }\end{array}$ & 4 & 4 & 4 & 4 & \\
\hline \multirow[t]{4}{*}{2.} & Keterpaduan & $\begin{array}{l}\text { 5. Kesesuaian urutan antar frame } \\
\text { dengan narasi }\end{array}$ & 3 & 4 & 4 & 3,66 & \multirow[t]{4}{*}{3,58} \\
\hline & & $\begin{array}{l}\text { 6. Ketepatan pemilihan backsound } \\
\text { pada media video animasi Powtoon }\end{array}$ & 3 & 4 & 4 & 3,66 & \\
\hline & & $\begin{array}{l}\text { 7. Sinkronisasi antara backsound dan } \\
\text { suara narator }\end{array}$ & 3 & 3 & 3 & 3 & \\
\hline & & $\begin{array}{l}\text { 8. Ketepatan dalam pemilihan } \\
\text { background pada media video } \\
\text { animasi Powtoon }\end{array}$ & 4 & 4 & 4 & 4 & \\
\hline 3. & Penekanan & $\begin{array}{l}\text { 9. Penekanan intonasi suara narator } \\
\text { pada frame tertentu }\end{array}$ & 4 & 3 & 3 & 3,33 & 3,33 \\
\hline \multirow[t]{2}{*}{4.} & Keseimbangan & $\begin{array}{l}\text { 10. Kejelasan gambar dan tulisan } \\
\text { yang digunakan dalam media } \\
\text { video animasi Powtoon }\end{array}$ & 3 & 4 & 4 & 3,66 & \multirow[t]{2}{*}{3,66} \\
\hline & & $\begin{array}{l}\text { 11. Keseimbangan tata letak tulisan } \\
\text { pada tiap frame yang digunakan } \\
\text { dalam media video animasi } \\
\text { Powtoon }\end{array}$ & 3 & 4 & 4 & 3,66 & \\
\hline 5. & Bentuk & $\begin{array}{l}\text { 12. Fleksibilitas dalam penggunaan } \\
\text { media video animasi Powtoon }\end{array}$ & 4 & 3 & 3 & 3,33 & 3,33 \\
\hline
\end{tabular}




\begin{tabular}{|c|c|c|c|c|c|c|c|}
\hline \multirow{2}{*}{ No. } & \multirow{2}{*}{ Aspek } & \multirow{2}{*}{ Kriteria Penilaian } & \multicolumn{3}{|c|}{ Validator ke- } & \multirow{2}{*}{$\mathbf{K i}$} & \multirow{2}{*}{$\mathbf{A} \mathbf{i}$} \\
\hline & & & 1 & 2 & 3 & & \\
\hline \multirow[t]{2}{*}{6.} & Warna & $\begin{array}{l}\text { 13. Penggunaan warna yang sesuai } \\
\text { pada tiap frame dalam media video } \\
\text { animasi Powtoon }\end{array}$ & 4 & 4 & 4 & 4 & 4 \\
\hline & & $\begin{array}{l}\text { RTV }_{\text {TK }} \\
\end{array}$ & & & & & 3,62 \\
\hline \multicolumn{8}{|c|}{ Keterangan: } \\
\hline $\mathrm{Ki}$ & & ata tiap kriteria & & & & & \\
\hline $\mathrm{Ai}$ & & ata tiap aspek & & & & & \\
\hline $\mathrm{RTV}_{\mathrm{TI}}$ & & ata total validasi & & & & & \\
\hline
\end{tabular}

Berdasarkan hasil analisis data validasi media oleh validator ahli media (Tabel 6) menunjukkan bahwa media video animasi Powtoon yang didesain termasuk dalam kategori valid dengan hasil $\mathrm{RTV}_{\mathrm{TK}}$ sebesar 3,62. Sejalan dengan itu hasil perhitungan Ai juga dinyatakan valid karena memenuhi kriteria validitas berdasarkan Khabibah dalam Yamasari (2010) yaitu $3 \leq \mathrm{RTV}_{\mathrm{TK}}$ $\leq 4$.

Nilai $\mathrm{RTV}_{\text {TK }}$ yang termasuk dalam kriteria valid menunjukkan bahwa media video animasi Powtoon yang didesain pada penelitian ini layak untuk digunakan sebagai media pembelajaran pada submateri peran tumbuhan di bidang ekonomi kelas X SMA dalam pembuatan biskuit pisang ambon lumut. Revisi dilakukan sesuai dengan saran validator ahli media. Kriteria penilaian pada tiap-tiap aspek dipaparkan sebagai berikut:

Aspek kesederhanaan yang dinilai pada media video animasi Powtoon terdiri dari empat kriteria penilaian yaitu kemudahan dalam mengakses media video animasi Powtoon, kemudahan dalam mengoperasikan media video animasi Powtoon, kesesuaian animasi yang disajikan dalam media video animasi Powtoon dengan karakteristik peserta didik, dan kemudahan dalam memahami kalimat yang digunakan pada media video animasi Powtoon. Aspek kesederhanaan secara keseluruhan dinyatakan valid dengan Ai sebesar 3,83. Keempat kriteria penilaian dinyatakan valid dengan perolehan masing-masing Ki sebesar 4; 4; 3,33 dan 4. Hal tersebut menunjukkan bahwa media video animasi Powtoon bersifat sederhana dan mudah dalam penggunaannya atau user friendly. Susilana \& Riyana (2009) menyatakan bahwa media yang bersifat user friendly adalah media yang bersahabat dengan penggunanya. Selain itu Hamidah (2005) juga menyatakan bahwa media dikatakan bersifat sederhana apabila bahan dasarnya mudah didapatkan, cara pembuatannya mudah, dan mudah dalam penggunaan medianya sehingga dapat mendukung tercapainya tujuan pembelajaran. Penggunaan bahasa atau kalimat yang sederhana dan mudah dipahami pada media video animasi Powtoon juga termasuk salah satu bentuk media yang bersifat user friendly. 
Media video animasi Powtoon pada aspek kesederhanaan mendapatkan beberapa saran penilaian oleh validator ahli media yang mengemukakan bahwa animasi yang terdapat pada media cukup variatif namun animasi relatif sama atau bersifat berulang. Berdasarkan hal tersebut disarankan media tidak terkesan monoton dan perlu dilakukan revisi terhadap media video animasi Powtoon, dimana animasi yang digunakan pada media lebih variatif.

Aspek keterpaduan yang dinilai pada media video animasi Powtoon terdiri dari empat kriteria penilaian. Kriteria penilaian pertama pada aspek keterpaduan yaitu kesesuaian urutan antar frame dengan narasi yang memperoleh nilai Ki sebesar 3,66 dinyatakan valid. Hamalik (2010) memaparkan bahwa keruntutan merupakan hal terpenting dalam penyampaian suatu cerita yang bertujuan untuk memberikan gambaran secara lebih jelas kepada audiens terkait urutan atau rangkaian terjadinya suatu hal. Kemudian kriteria penilaian kedua pada aspek keterpaduan yaitu ketepatan pemilihan backsound pada media video animasi Powtoon yang memperoleh nilai Ki sebesar 3,66 dinyatakan valid. Nurseto (2011) menyatakan bahwa penggunaan backsound music pada media pembelajaran bertujuan untuk memperkuat sebuah situasi tertentu. Sadiman, Rahardjo, Haryono, \& Harjito (2012) menyatakan bahwa backsound musik umumnya berupa musik instrumen dengan volume yang tidak boleh terlalu keras, terlalu lemah maupun berubah-ubah dari lemah ke keras atau sebaliknya. Selanjutnya kriteria penilaian ketiga pada aspek keterpaduan yaitu sinkronisasi antara backsound dan suara narator yang memperoleh nilai Ki sebesar 3 dinyatakan valid. Setelah itu kriteria penilaian keempat yaitu ketepatan dalam pemilihan background pada media video animasi Powtoon yang memperoleh nilai Ki sebesar 4 dinyatakan valid. Volume backsound tidak boleh lebih dominan dari volume suara narator dan background yang digunakan pada media harus sederhana, kontras dan konsisten, serta hindari background yang rumit, mengganggu, dan penuh.

Aspek keterpaduan secara keseluruhan dinyatakan valid dengan Ai sebesar 3,58. Oleh karena itu, aspek keterpaduan pada media video animasi Powtoon telah memenuhi seluruh kriteria. Pada aspek keterpaduan terdapat beberapa saran dari validator ahli media pada media video animasi Powtoon berupa narasi relatif sama atau berulang, icon dengan suara narator disesuaikan, dan backsound seperti berkompetisi dengan volume suara narator pada beberapa scene sehingga dilakukan revisi terhadap media tersebut. Narasi yang relatif sama atau terkesan berulang pada media video animasi Powtoon direvisi sehingga narasi yang terdapat pada media tersebut tidak terkesan berulang dan sama. Kemudian icon yang terdapat pada media video animasi Powtoon sudah sesuai dengan suara narator. Selanjutnya pada beberapa scene narasi terlalu cepat dan bersambungan terlalu dekat dengan kalimat sebelumnya sehingga perlu dilakukan revisi terhadap suara narator agar narasi yang terdengar tidak terlalu cepat dan bersambungan terlalu dekat dengan kalimat sebelumnya. Selain itu pada beberapa scene, backsound seperti berkompetisi dengan volume suara narator sehingga perlu dilakukan revisi, 
sehingga volume suara narator yang terdengar lemah atau terkesan sama dengan volume backsound tidak terdengar berkompetisi.

Aspek penekanan yang dinilai pada media video animasi Powtoon terdiri dari satu kriteria penilaian yaitu penekanan intonasi suara narator pada frame tertentu. Kadaruddin (2016) menyatakan penekanan merupakan suatu bentuk penyajian konsep yang ditempatkan pada unsur-unsur penting untuk memusatkan minat dan perhatian peserta didik. Berdasarkan hal tersebut aspek penekanan yang diberikan adalah intonasi suara narator pada frame tertentu yang bertujuan untuk memusatkan minat, perhatian, dan fokus peserta didik terhadap informasi yang disampaikan melalui media video animasi Powtoon. Pada aspek penekanan validator menilai bahwa suara narator menggunakan intonasi dan penekanan yang berbeda. Secara keseluruhan aspek penekanan dinyatakan valid dengan perolehan masing-masing nilai Ki dan Ai sebesar 3,33. Dengan demikian, aspek penekanan pada media video animasi Powtoon telah memenuhi kriteria kelayakan untuk digunakan sebagai media pembelajaran.

Aspek keseimbangan yang dinilai pada media video animasi Powtoon terdiri dari dua kriteria penilaian yaitu kejelasan gambar dan tulisan yang digunakan dalam media video animasi Powtoon dan keseimbangan tata letak tulisan pada tiap frame yang digunakan dalam media video animasi Powtoon. Kentut (2010) menyatakan keseimbangan tata letak gambar dan tulisan pada setiap tampilan sangat penting dalam media pembelajaran. Kriteria penilaian ini dinyatakan valid dengan perolehan masingmasing Ki sebesar 3,66 dan 3,66. Validasi aspek keseimbangan secara keseluruhan dinyatakan valid dengan Ai sebesar 3,66. Pada aspek keseimbangan terdapat saran penilaian dari validator ahli media pada media video animasi Powtoon berupa logo Powtoon menutupi tabel atau gambar pada kanan bawah video sehingga dilakukan revisi kembali. Dengan demikian, aspek keseimbangan pada media video animasi Powtoon telah memenuhi kriteria kelayakan untuk digunakan sebagai media pembelajaran.

Aspek bentuk yang dinilai pada media video animasi Powtoon terdiri dari satu kriteria penilaian yaitu fleksibilitas dalam penggunaan media video animasi Powtoon. Fleksibilitas pada aspek bentuk berarti bahwa media video animasi Powtoon dalam pembelajaran dapat digunakan oleh peserta didik secara mandiri, kelompok maupun perkelas serta dapat digunakan sebagai alat bantu pada saat pembelajaran secara praktikum maupun teori. Pada aspek bentuk menurut validator bahwa media video animasi Powtoon untuk alat bantu pada saat pembelajaran secara praktikum diperlukan fokus pada prosedur sehingga tahapan pembuatan biskuit pisang ambon lumut dapat tergambar dengan jelas. Nurrita (2018) menyatakan guru harus memilih media yang fleksibel sehingga dapat digunakan dalam berbagai situasi. Aspek bentuk secara keseluruhan dinyatakan valid dengan perolehan masing- 
masing nilai Ki dan Ai sebesar 3,33. Dengan demikian, aspek bentuk pada media video animasi Powtoon telah memenuhi kriteria kelayakan untuk digunakan sebagai media pembelajaran.

Aspek warna yang dinilai pada media video animasi Powtoon terdiri dari satu kriteria penilaian yaitu penggunaan warna yang sesuai pada tiap frame dalam media video animasi Powtoon. Secara keseluruhan aspek warna dinyatakan valid dengan perolehan masing-masing nilai Ki dan Ai sebesar 4. Pada aspek warna validator menilai media video animasi Powtoon mempunyai kombinasi warna kontras untuk membedakan antara figure dan background, kesesuaian perpaduan warna yang digunakan antara background dan tulisan, dan warna kontras antara tulisan dengan gambar yang ada pada tiap frame. Sudjana \& Rivai (2013) menyatakan warna yang ditampilkan dalam sebuah media harus terlihat harmonis dan jauh dari kesan kumuh yang akan mengganggu pengamatan peserta didik. Sejalan dengan hal tersebut, Purnama (2010) menyatakan pewarnaan yang baik harus memperhatikan keselarasan (harmoni) terhadap unsur-unsur multimedia yang meliputi teks, gambar, background, dan simbol-simbol sehingga dapat memberikan kesan yang kuat dan mempermudah peserta didik dalam mengingat terkait materi-materi yang tercantum dalam multimedia pembelajaran. Dengan demikian, aspek warna pada media video animasi Powtoon telah memenuhi kriteria kelayakan untuk digunakan sebagai media pembelajaran.

\section{SIMPULAN}

Media video animasi Powtoon pada submateri peran tumbuhan di bidang ekonomi kelas $\mathrm{X}$ SMA dalam pembuatan biskuit pisang ambon lumut yang telah divalidasi oleh validator ahli materi memperoleh nilai rata-rata total validasi $\left(\mathrm{RTV}_{\text {TK }}\right)$ sebesar 3,57 dengan kategori valid dan hasil validasi oleh validator ahli media memperoleh nilai rata-rata total validasi ( $\left.\mathrm{RTV}_{\text {TK}}\right)$ sebesar 3,62 dengan kategori valid. Dengan demikian, media video animasi Powtoon layak digunakan sebagai media pembelajaran pada submateri peran tumbuhan di bidang ekonomi kelas X SMA.

\section{UCAPAN TERIMA KASIH}

Terima kasih kepada validator-validator ahli materi maupun ahli media dari Pendidikan Biologi FKIP Universitas Tanjungpura, SMA Negeri 1 Sungai Raya, dan SMA Negeri 2 Sungai Raya yang telah memberikan izin dan bersedia memvalidasi media video animasi Powtoon, Payung Penelitian Teknologi Tepat Guna (TTG) yang telah memberikan dana riset untuk penelitian. 


\section{REFERENSI}

Arsyad, A. (2016). Media Pembelajaran. Jakarta: PT Raja Grafindo Persada.

Astuti, T. (2015). Manajemen Praktikum Pembelajaran IPA. Jurnal Manajer Pendidikan, 9(1), 57-64.

Badan Pusat Statistik Provinsi [BPS] Kalimantan Barat. (2018). Statistik Pertanian Tanaman Sayuran dan Buah-buahan Kalimantan Barat Tahun 2018. Pontianak: Badan Pusat Statistik Provinsi Kalimantan Barat.

Dewi, T. A. (2015). Implementasi Multimedia Interaktif dalam Pembelajaran Ekonomi di Sekolah. Jurnal Pendidikan Ekonomi UM Metro, 3(2), 1-10.

Ernalida., Lidyawati, Y., Ansori., Gafur, A., Hikmah, N., \& Utami, R. (2018). Powtoon: Media Pembelajaran Berbasis Teknologi Informasi sebagai Upaya dalam Menciptakan Pembelajaran yang Menarik dan Kreatif. LOGAT: Jurnal Bahasa Indonesia dan Pembelajaran, 5(2), 132-138. https://doi.org/10.36706/logat.v5i2.57

Hamalik, O. (2010). Proses Belajar Mengajar. Jakarta: Bumi Aksara.

Hamidah. (2005). Peranan Penggunaan Media Sederhana dalam Meningkatkan Efektivitas Proses Belajar Mengajar Bidang Studi Pendidikan Agama Islam di MIN Johar Baru Jakarta Pusat. UIN Syarif Hidayatullah Jakarta. Skripsi. Diterbitkan.

Hasanah, R., Daningsih, E., \& Titin. (2017). The Analysis of Nutrient and Fiber Content of Banana (Musa paradisiaca) Sold in Pontianak, Indonesia. Biofarmasi (Rumphius J Nat Prod Biochem), 15(1), 21-25. 10.13057/biofar/f150104

Istiqomah, G., Daningsih, E., \& Yokhebed. (2016). Kelayakan Multimedia Interaktif Anatomi Daun Kelas XI SMA. Jurnal Pendidikan dan Pembelajaran Khatulistiwa, 5(3), 1-10.

Juliana., Erviyenni., \& Rini. (2017). Pengembangan Media Pembelajaran Berbasis Powtoon pada Pokok Bahasan Struktur Atom di Kelas X SMA/sederajat. Jurnal Online Mahasiswa Fakultas Keguruan dan Ilmu Pendidikan, 4(2), 1-10.

Kadaruddin. (2016). Media dan Multimedia Pembelajaran (Cetakan ke-2 ed.). Yogyakarta: Deepublish.

Kentut. (2010). Modul Pembuatan Media Presentasi. Jakarta: Kementerian Pendidikan Nasional.

Munadi, Y. (2013). Media Pembelajaran (Sebuah Pendekatan Baru). Jakarta: Referensi (Gaung Persada Press Group).

Nurrita, T. (2018). Pengembangan Media Pembelajaran untuk Meningkatkan Hasil Belajar Siswa. Misykat, 3(1), 171-187. http://dx.doi.org/10.33511/misykat.v3n1.171

Nurseto, T. (2011). Membuat Media Pembelajaran yang Menarik. Jurnal Ekonomi dan Pendidikan, 8(1), 19-35. https://doi.org/10.21831/jep.v8i1.706

Pangestu, B. A. (2017). Pemanfaatan Media Pembelajaran dalam Pendidikan. Seminar Nasional Pendidikan, 121-126. Malang: Pendidikan IPS Universitas Negeri Malang. 
Pangestu, M. D., \& Wafa, A. A. (2018). Pengembangan Multimedia Interaktif Powtoon pada Mata Pelajaran Ekonomi Pokok Bahasan Kebijakan Moneter untuk Siswa Kelas XI IPS di SMA Negeri 1 Singosari. Jurnal Pendidikan Ekonomi, 11(1), 71-79. https://dx.doi.org/10.179 77/UM014v11i12018p071

Prastowo, A. (2013). Panduan Kreatif Membuat Bahan Ajar Inovatif. Yogyakarta: Diva Press.

Purnama, S. (2010). Elemen Warna dalam Pengembangan Multimedia Pembelajaran Agama Islam. Jurnal Al-Bidayah, 2(1), 113-129. https://doi.org/10.14421/al-bidayah.v2i1.102

Sadiman, A. S., Rahardjo, R., Haryono, A., \& Harjito. (2012). Media Pendidikan: Pengertian, Pengembangan, dan Pemanfaatannya. Jakarta: PT Raja Grafindo Persada.

Sadiman, A. S., Rahardjo, R., Haryono, A., \& Harjito. (2014). Media Pendidikan: Pengertian, Pengembangan, dan Pemanfaatannya. Jakarta: PT Raja Grafindo Persada.

Sari, P. (2019). Analisis Terhadap Kerucut Pengalaman Edgar Dale dan Keragaman Gaya Belajar untuk Memilih Media yang Tepat dalam Pembelajaran. Mudir: Jurnal Manajemen Pendidikan, 1(1), 58-78. https://doi.org/10.36835/mudir.v1i1.27

Sudjana, N., \& Rivai, A. (2013). Media Pengajaran. Bandung: Sinar Baru Algensindo.

Suryani, N., Setiawan, A., \& Putria, A. (2018). Media Pembelajaran Inovatif dan Pengembangannya. Bandung: PT Remaja Rosdakarya.

Susilana, R., \& Riyana, C. (2009). Media Pembelajaran: Hakikat, Pengembangan, Pemanfaatan, dan Penilaian. Bandung: CV Wacana Prima.

Yamasari, Y. (2010). Pengembangan Media Pembelajaran Matematika Berbasis ICT yang Berkualitas. Seminar Nasional Pascasarjana X-ITS, 1-8. Surabaya: Matematika Universitas Negeri Surabaya. 